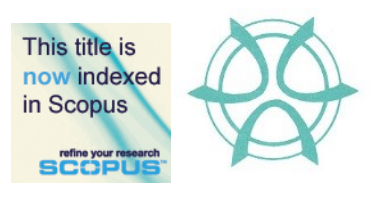

PLANNING MALAYSIA:

Journal of the Malaysian Institute of Planners

VOLUME 19 ISSUE 5 (2021), Page $14-25$

\section{TRAFFIC CONGESTIONS, TIME SPENT AT THE EXPRESSWAY JUNCTIONS, AND ITS IMPACT ON INDIVIDUAL PRODUCTIVITY: A PERCEPTION STUDY OF ILESA-OWO-BENIN EXPRESSWAY IN AKURE ONDO STATE, NIGERIA}

\author{
Omotayo Fatai Ogunyemi ${ }^{1}$, Diana Binti Mohamad ${ }^{2}$, Nurwati \\ Badarulzaman ${ }^{3}$, Abdul Ghapar Othman ${ }^{4}$ \\ ${ }^{1,2,3,4}$ School of Housing, Building and Planning \\ UNIVERSITI SAINS MALAYSIA
}

\begin{abstract}
The importance of the free flow of traffic, time spent in traffic at junctions, and individual productivity of road users along the Ilesa-Owo-Benin expressway in Akure Ondo State, Nigeria, cannot be overstated. While extant literature has shown that traffic congestion on roads significantly influences how road users perform their duties, few studies have explored the part played by the length of time they spend at junctions and how it impacts individual productivity. We collected data using a Questionnaire survey, comprising questions associated with traffic congestion at junctions of 203 respondents from across the residents (and travellers through Agbogbo/Irese/Futa junctions along Ilesa-Owo-Benin expressway in Akure). With an analysis of variance (ANOVA), we identified the differences in road users' perception of traffic congestions at junctions. We investigated the impact of traffic congestion on the productivity of road users. Finally, we identified potential solutions to the persistent traffic congestion experienced at the junctions. This paper offers a traffic congestion community with a better understanding of traffic congestions on road networks and aid in developing suitable methods and policies for road traffic congestion management.
\end{abstract}

Keywords: Road, Junctions, Flow, Traffic Congestion, Cities, Urban Areas

\footnotetext{
${ }^{2}$ Lecturer at University Sains Malaysia Email: diana_mohamad@usm.my
} 


\section{INTRODUCTION}

Road Junctions are locations of high traffic concentration, and in most countries, $40-60 \%$ of the total number of traffic congestions occurs at junctions (European Commission Transport Road Safety, 2020). As noted by Bashiru and Waziri (2008), most Nigerian road users, particularly commuters and motorists, spend between 30 to 60 minutes in traffic due to congestions. A closer look at the traffic flow in Akure, a major city in Nigeria, it can be said that most traffic congestions occur at the start of the workweek (Mondays and Tuesdays). Similarly, significant traffic congestions in other major cities in Nigeria have been noted. Agbonika (2011) examined the Abuja City Road network, while Aderamo \& Atomode (2012) observed the road junctions in Ilorin. Both authors noted extensive traffic congestion on Mondays. In most circumstances, traffic congestions are caused by gridlocks at the preceding junctions, potholes, trading activities, public transport vehicles when loading and discharging passengers, and inadequate or the lack of traffic lights at junctions.

Junctions, irrespectively of the number of interlocking roads, are defined as the intersection of roads where the vehicles' flow is controlled by traffic police or traffic light (Singha \& Kalita, 2016). They are intended to operate where vehicles often share space with other vehicles and pedestrians anywhere in the world. The primary objective of a junction is to enhance all road users' efficient movement, such as motor vehicles, buses, trucks, bicycles, and pedestrians, and increase convenience, comfort, and safety on the road (Fitzpatrick et al., 2005). However, due to its interlinking nature, junctions are prone to traffic congestion (Fadairo, 2013) as vehicles and motorists attempt to use the connecting junctions to their destination.

A traffic stream is a group of vehicles to pass towards a road through a junction (Singha \& Kalita, 2016). Vehicular flows at the junctions show vehicles from several different approaches. They intend to occupy the same physical space simultaneously, allowing the increased flow of vehicles that will cause traffic congestion and incur longer waiting times for the stream of vehicles. It becomes so essential that interest should be given when determining the type of junctions and the number of junctions along a road corridor and the proper design of each to ease traffic. In this study, we discussed the persistent traffic congestion at major road junctions in Akure city. The aim is to provide case study evidence of traffic Congestions, time Spent at the expressway junctions, and their impact on the individual productivity road users.

\section{METHODOLOGY}

This paper provides a case study of traffic congestions, time spent at the expressway junctions, and its impact on individual productivity: A perception study of Ilesa-Owo-Benin expressway in Akure Ondo State, Nigeria. A case of 
Omotayo Fatai Ogunyemi, Diana Binti Mohamad, Nurwati Badarulzaman, Abdul Ghapar Othman Traffic Congestions, Time Spent at The Expressway Junctions, And Its Impact on Individual Productivity: A Perception Study of Ilesa-Owo-Benin Expressway in Akure Ondo State, Nigeria

Agbogbo/Irese/Futa Junctions and the impedance to the continuous free flow of vehicles leading to traffic congestion at the junctions. These junctions were selected because they link significant roads within the city and connect Ondo state with other states like Oyo, Osun, Ekiti, and Edo.

- Objective 1: To examine road users' opinion on the traffic situation on Ilesa-Owo-Benin expressway, Akure, i.e., the cause and effect on their productivity.

- Objective 2: To identify the wait time (time spent) at the junctions during heavy traffic congestions at Agbogbo/Irese/Futa junctions.

- Objective 3: To highlight road users' suggestions towards overcoming the traffic congestions at Agbogbo/Irese/Futa junctions.

Based on recommendations from previous studies, a questionnaire was designed with closed-ended questions and administered to the daily road users and commuters at the three junctions. The questions targeted their experiences and perception of time spent, traffic congestions at the expressway junctions, and its impact on productivity and proximity. The responses were designed on an option-based scale and a five-point scale. A minimum of 250 responses was targeted as representative of the daily road users. To achieve this target, we used convenience sampling method to collect data required. Out of the 250 responses received, 203 responses were deemed valid. The responses retrieved were processed and analysed via IBM SPSS Statistics 21 . The results and findings are presented and discussed in the sections below.

\section{FINDINGS AND BACKGROUND INFORMATION}

Most of the respondents were aged between 25 - 31 years and $32-38$ years $(31.03 \%$ \& $30.05 \%$ respectively) with a considerable number aged group between $39-45$ years $(18.72 \%)$. However, other participants include $18-24$ years $(11.33 \%)$ and 46 and above (8.87\%). There was a relatively even distribution of male and female respondents in the survey, with $57.64 \%$ Males and $42.36 \%$ Females. Most data were collected from the employed 51.23\%, who about $61.58 \%$ of them primarily residents in the study area. Table 1 shows the information and details obtained about age group, gender, occupation, educational status, and locality.

Table 1: Respondents Backgrounds

\begin{tabular}{|l|l|l|l|l|l|}
\hline Background & \multicolumn{5}{|l|}{ Counts (\%) } \\
\hline Age & $\begin{array}{l}18-24 \\
(11.33 \%)\end{array}$ & $\begin{array}{l}25-31 \\
(31.03 \%)\end{array}$ & $\begin{array}{l}32-38 \\
(30.05 \%)\end{array}$ & $\begin{array}{l}39-45 \\
(18.72 \%)\end{array}$ & $\begin{array}{l}46> \\
(8.87 \%)\end{array}$ \\
\hline Gender & $\begin{array}{l}\text { Male } \\
(57.64 \%)\end{array}$ & Female (42.36\%) & & & \\
& & & & \\
\hline
\end{tabular}


PLANNING MALAYSIA

Journal of the Malaysia Institute of Planners (2021)

\begin{tabular}{|l|l|l|l|l|l|}
\hline Occupation & $\begin{array}{l}\text { Employed } \\
(51.26 \%)\end{array}$ & $\begin{array}{l}\text { Unemployed } \\
(13,79 \%)\end{array}$ & $\begin{array}{l}\text { Self- } \\
\text { Employed } \\
(26.11 \%)\end{array}$ & $\begin{array}{l}\text { Retiree } \\
(0.49 \%)\end{array}$ & $\begin{array}{l}\text { Student } \\
(8.37 \%)\end{array}$ \\
\hline Education & $\begin{array}{l}\text { No formal } \\
\text { Education } \\
(0.99 \%)\end{array}$ & $\begin{array}{l}\text { Primary/Secondary } \\
(15.76 \%)\end{array}$ & $\begin{array}{l}\text { NCE/OND } \\
(22.66 \%)\end{array}$ & $\begin{array}{l}\text { HND/BSc } \\
(52.71 \%)\end{array}$ & $\begin{array}{l}\text { Postgrad } \\
(7.88 \%)\end{array}$ \\
\hline Locality & $\begin{array}{l}\text { Resident } \\
(61.58 \%)\end{array}$ & $\begin{array}{l}\text { Non-Resident } \\
(22.17 \%)\end{array}$ & $\begin{array}{l}\text { Tourist } \\
(3.48 \%)\end{array}$ & $\begin{array}{l}\text { Business } \\
\text { Owner } \\
(7.88 \%)\end{array}$ & $\begin{array}{l}\text { Public } \\
\text { Transp. } \\
(4.93 \%)\end{array}$ \\
\hline
\end{tabular}

\section{Traffic Congestion at the Junctions}

The respondents were asked to choose how often they get stuck at the junctions due to traffic congestion. As shown in Figure 3, most of the respondents, 84 (41.4\%), responded that they got stuck in traffic congestion at the junctions daily. Considering that $61.58 \%$ of the respondents are residents (Table 1), this is suggesting that most of the respondents use the road every day. However, 39.4\% of the respondents, 80 out of 203, get stuck a few times a week. Also, $39(19.2 \%)$ respondents get stuck a few times a month, implying that they often don't use the road. Based on Table 1, wherein $22.17 \%$ are non-residents, $7.88 \%$ are business owners, $4.93 \%$ are public transporter, and $3.45 \%$ are tourists, we can conclude that these are the groups of road users who get stuck in traffic a few times a week and a few times in a month.

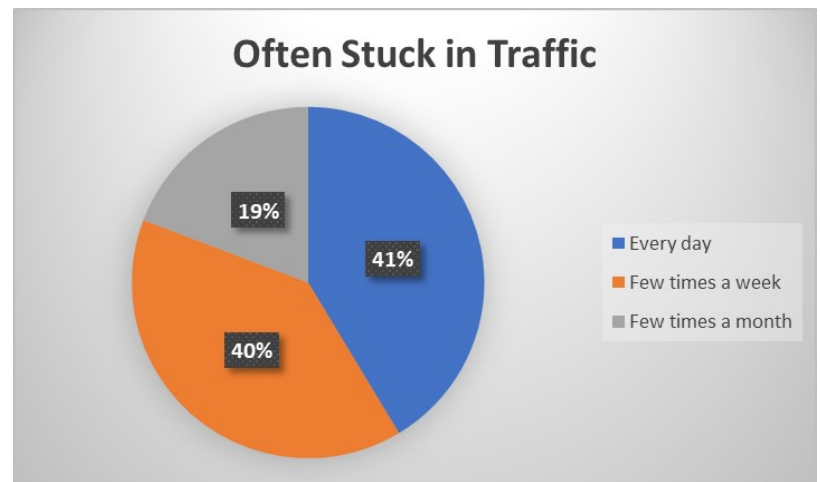

Figure 1: Respondents' opinion on how often they get stuck in traffic at the junctions Source: Fieldwork 2021

The respondents' opinions on what they thought caused the traffic congestions were retrieved (Figure 4). About fifty-two percent of the respondents $(51.7 \%)$ opined that the cause for the traffic congestion at these junctions was poor road infrastructure. In comparison, $58(28.6 \%)$ opined that too many vehicles on the road were to be blamed for the congestions while $38(18.7 \%)$ and 
Omotayo Fatai Ogunyemi, Diana Binti Mohamad, Nurwati Badarulzaman, Abdul Ghapar Othman

Traffic Congestions, Time Spent at The Expressway Junctions, And Its Impact on Individual Productivity: A

Perception Study of Ilesa-Owo-Benin Expressway in Akure Ondo State, Nigeria

$2(1 \%)$ felt that the reasons are the commercial activities at the junctions and other problems respectively.

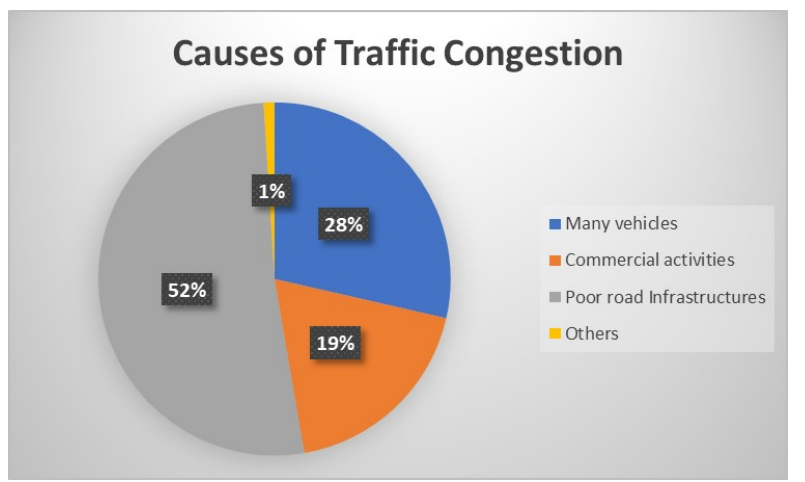

Figure 2: Respondents' opinion on causes of traffic congestion at the junctions Source: Fieldwork 2021

Past works maintain that traffic congestions are regular on roads with several junctions and proximity of junctions (Simeon et al., 2018, Eom \& Kim, 2020, Erdelic et al., 2021). To test this past result, we asked the participants to respond to the statement was, "The continuous traffic congestion at the junctions is the result of proximity between the junctions." As depicted in Table 2, 53.7\% agreed and strongly agreed with the statement, while $19.7 \%$ disagree and strongly disagreed with the statement. Twenty-six percent $(26.6 \%)$ were unsure if the statement was true or false.

Similarly, previous studies have indicated that traffic congestion affects the individual productivity of road users (Kamruzzaman \& Rumpa, 2019, Olawale et al., 2015, Harriet et al., 2013). As such, we asked the participants to respond to the statement, "The continuous traffic congestion at the junctions impacts on my productivity." About sixty-five percent (64.5\%) agreed and strongly agreed that continuous traffic congestions impacted productivity. Only $20.2 \%$ disagreed and strongly agreed with its impact on productivity. Twentyfive percent of the respondents were unsure.

Table 2: Respondents opinion on proximity of junctions and its impact on productivity

\begin{tabular}{|c|c|c|}
\hline Scales & Proximity of junctions & $\begin{array}{c}\text { Impact on individual } \\
\text { productivity }\end{array}$ \\
\hline Strongly Disagree & $05(2.5 \%)$ & $15(7.4 \%)$ \\
\hline Disagree & $35(17.2 \%)$ & $26(12.8 \%)$ \\
\hline Not sure & $54(26.6 \%)$ & $51(25.1 \%)$ \\
\hline Agree & $90(44.3 \%)$ & $97(47.8 \%)$ \\
\hline Strongly Agree & $19(9.4 \%)$ & $34(16.7 \%)$ \\
\hline Total & $203(100 \%)$ & $203(100 \%)$ \\
\hline
\end{tabular}




\section{Waiting time spent in traffic congestion at the junctions}

Research shows that vehicle traffic slows down when roads get jammed with high-volume congestion (Ross, 2012, Wang et al., 2018, Nguyen-Phuoc et al., 2020). Based on these studies, we investigated the wait time road users spent in traffic and the impact on individual productivity., the respondents were asked how much time they spent in traffic at Agbogbo/Irese/Itaoniyan Junctions for a single journey during the weekdays (Monday - Friday). Traffic during the weekends was not investigated because they do not generally relate to work productivity.

The length of time was considered based on when there was Heavy Traffic (respondents spent more than 10mins at the junctions) and Seldom Traffic (respondents spent less than 10 mins at the junctions).

As shown in Table 3, a considerable number of respondents spent 20 minutes at that junction when there was heavy traffic $(97,47.8 \%)$. This is followed by 60 respondents $(29.6 \%)$ and 37 respondents $(18.2 \%)$ who spent 15 minutes and 25 minutes, respectively. Only 09 respondents $(4.4 \%)$ reported spending 10 minutes in traffic. Deductively, most of the respondents spend a lot of time at the junctions due to the heavy traffic.

In contrast, when there is seldom traffic at the junctions, many respondents spent 10 minutes or less travelling through the junctions $(69,34.0 \%)$. However, the differences are not too apparent in the time spent at junctions by the respondents' responses. Most of the respondents also spent a lot of time getting at the junctions with seldom traffic. Seventy-one respondents (35\%), spent 15 minutes, while 42 respondents $(20.7 \%)$ and 21 respondents $(10.3 \%)$ spent 20 minutes and 25 minutes, respectively.

Table 3: Waiting Time Spent at the Junctions

\begin{tabular}{|c|c|c|c|c|}
\hline \multirow{2}{*}{$\begin{array}{c}\text { Waiting Time Spent } \\
\text { (mins) }\end{array}$} & \multicolumn{2}{|c|}{ Heavy traffic } & \multicolumn{2}{c|}{ Seldom traffic } \\
\cline { 2 - 5 } & $\mathbf{N}$ & $\mathbf{\%}$ & $\mathbf{N}$ & $\%$ \\
\hline $\mathbf{1 0}$ mins & 09 & $(4.4 \%)$ & 69 & $(34.0 \%)$ \\
\hline $\mathbf{1 5}$ mins & 60 & $(29.6 \%)$ & 71 & $(35.0 \%)$ \\
\hline $\mathbf{2 0}$ mins & 97 & $(47.8 \%)$ & 42 & $(20.7 \%)$ \\
\hline $\mathbf{2 5}$ mins & 37 & $(18.2 \%)$ & 21 & $(10.3 \%)$ \\
\hline Total & 203 & $(100 \%)$ & 203 & $(100 \%)$ \\
\hline
\end{tabular}

To ascertain whether there was any significant difference in opinion amongst the respondents on time spent at the junctions, they were asked to choose the period when they experienced heavy traffic congestion during a weekday - Morning (7$11 \mathrm{am})$; Afternoon (12-3 pm) and Evening (4-6 pm). An analysis of variance (ANOVA) was carried out at a $95 \%$ confidence interval $(p<0.05)$ (Witton et al., 2019). Table 4 shows that heavy traffic is experienced most during the mornings 
Omotayo Fatai Ogunyemi, Diana Binti Mohamad, Nurwati Badarulzaman, Abdul Ghapar Othman Traffic Congestions, Time Spent at The Expressway Junctions, And Its Impact on Individual Productivity: A Perception Study of Ilesa-Owo-Benin Expressway in Akure Ondo State, Nigeria

(46.3\%) than other times of the day (afternoons $-15.8 \%$; evenings $-9.4 \%$ ). Interestingly, $28.6 \%$ of the respondents reported no specific time when they experienced heavy traffic during the weekdays.

A glance at the descriptive statistics shows that our sample data produces a difference in the mean scores of the four levels of our regularity of road use variable. Specifically, the data analysis shows that the evening (weekdays) subjects spend quite a bit more time in traffic than subjects in the other three groups (Min. time $=15$ mins; Max. time $=25$ mins). However, to determine whether the difference in mean scores reaches significance, homogeneity of variance (a requirement for the ANOVA test) was carried out, which shows that the variances of each comparison group are equal. Tested using the Levene statistic showed a greater significance value than $0.05(\mathrm{p}>0.05)$.

The Levene statistic based on a comparison of medians is 0.937 , which implies that there is no significant difference in opinion amongst the respondents between when they experienced heavy traffic and the wait time they spent in traffic. Hence, an Honest Significant Difference test (Tukey HSD) was not required. The requirement of homogeneity of variance has been met, and the ANOVA test is considered robust.

Table 4: Mean values, Test of Homogeneity of variances amongst respondents' on how often they use and how long wait at the junctions during more traffic congestions.

\begin{tabular}{|c|c|c|c|c|c|c|c|c|c|}
\hline \multirow{2}{*}{$\begin{array}{c}\text { How } \\
\text { often } \\
\text { (Road } \\
\text { Use) }\end{array}$} & \multirow[t]{2}{*}{$\mathbf{N}$} & \multirow[t]{2}{*}{$\%$} & \multirow[t]{2}{*}{ Mean } & \multirow[t]{2}{*}{$\begin{array}{l}\text { Std. } \\
\text { Devi. }\end{array}$} & \multirow{2}{*}{$\begin{array}{l}\text { Std. } \\
\text { Err } \\
\text { or }\end{array}$} & \multicolumn{2}{|c|}{$\begin{array}{l}\text { 95\% Confidence } \\
\text { Interval for Mean }\end{array}$} & \multirow{2}{*}{$\begin{array}{l}\text { Min. } \\
\text { wait. } \\
\text { time }\end{array}$} & \multirow{2}{*}{$\begin{array}{l}\text { Max. } \\
\text { wait. } \\
\text { time }\end{array}$} \\
\hline & & & & & & $\begin{array}{l}\text { Lower } \\
\text { Bound }\end{array}$ & $\begin{array}{l}\text { Upper } \\
\text { Bound }\end{array}$ & & \\
\hline Morn. & 94 & 46.3 & 18.56 & 3.854 & .397 & 17.77 & 19.35 & 10 & 25 \\
\hline Aftern. & 32 & 15.8 & 18.91 & 3.753 & .664 & 17.55 & 20.26 & 10 & 25 \\
\hline Even. & 19 & 9.4 & 19.74 & 3.899 & .895 & 17.86 & 21.62 & 15 & 25 \\
\hline $\begin{array}{c}\text { No } \\
\text { specific }\end{array}$ & 58 & 28.6 & 19.48 & 4.156 & .546 & 18.39 & 20.58 & 10 & 25 \\
\hline Total & 203 & 100 & 18.99 & 3.929 & .276 & 18.45 & 19.53 & 10 & 25 \\
\hline \multicolumn{10}{|c|}{ Test of Homogeneity of Variances } \\
\hline \multicolumn{3}{|c|}{ Levene Statistic } & df1 & df 2 & \multicolumn{5}{|c|}{ Sig. } \\
\hline \multicolumn{3}{|c|}{.138} & 3 & 199 & \multicolumn{5}{|c|}{$.937 * *$} \\
\hline
\end{tabular}

$\mathrm{df}=$ Degree of Freedom; $\mathrm{p}=$ significance ${ }^{* *} ;$ Morn. $=$ Morning $(7-11 \mathrm{am}) ;$ Aftern. $=$ Afternoon (12$3 \mathrm{pm})$; Even. = Evening $(4-6 \mathrm{pm})$

\section{Overcoming traffic congestions at the junctions}

Regarding suggested solutions to overcome the traffic congestions at the junctions (Figure 5), 85 respondents (41.9\%) suggested providing a flyover to contain more cars on the road. About thirty-four percent $(33.5 \%)$ of the respondents suggested creating effective buffer zones around the junctions, and 
50 respondents $(24.6 \%)$ suggested providing functional traffic signals at the junctions. These showed that people who travel through these junctions want some form of infrastructure fixed at these junctions, with most numbers wanting a flyover at the junctions to ease the traffic congestion situation.

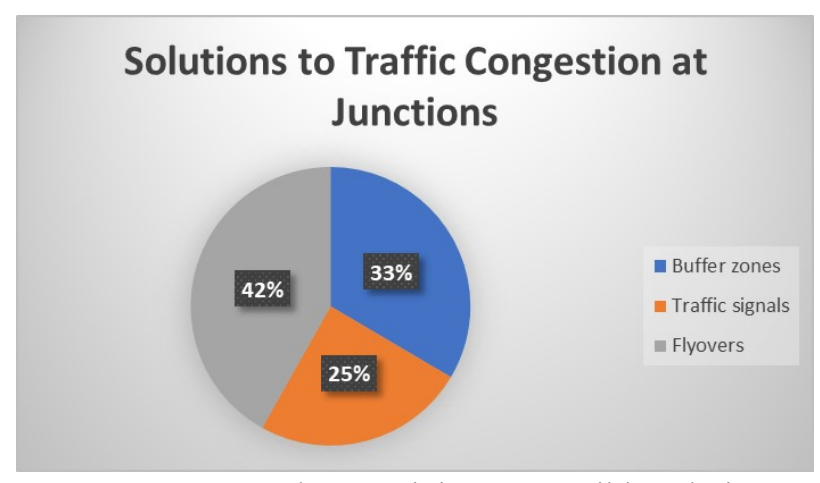

Figure 3: Respondents' opinion on possible solutions. Source: Fieldwork 2021

\section{DISCUSSION}

The findings from our analysis have identified essential aspects of the current traffic congestion experienced along the Ilesha-Owo-Benin expressway, Akure. We found that most of our respondents get stuck in traffic every day and a few times a week at the junctions. During these times, they spent an average of 20 mins in heavy traffic and 15 mins in seldom traffic. Most of the traffic congestions occur in the morning (at rush times between $7-11 \mathrm{am}$ ). Those who experienced traffic congestions in the evening reported spending a minimum of 15 mins in traffic at the junctions.

As expected, there was no significant difference in opinion between the periods of traffic (morning, afternoon, and evening) and the wait time spent at the junctions. This means that all the respondents agreed with their opinions. Our findings are no different from past works that have shown the traffic congestion in major cities across the globe. For instance, Moses (2011) argued that traffic congestion is a problem in most Nigerian cities. Aderamo \& Atomode (2012) examined traffic congestion problems and their causes at selected road intersections in Ilorin, Nigeria.

Lai et al. (2016) examined the traffic problems and sustainable improvement of road intersections at Ettumanoor, India. We acknowledge that the ubiquity of road traffic congestion at junctions is quite complex and requires proper planning at onstage. Just as synonymous with past studies are recurrent queues, delays, and time wastage commuters' experience on the road networks, especially during rush hours in Akure road networks. 
Omotayo Fatai Ogunyemi, Diana Binti Mohamad, Nurwati Badarulzaman, Abdul Ghapar Othman Traffic Congestions, Time Spent at The Expressway Junctions, And Its Impact on Individual Productivity: A Perception Study of Ilesa-Owo-Benin Expressway in Akure Ondo State, Nigeria

The problems of longer transit time between locations are pronounced by the waiting time at the road junctions and the respondents in our study felt that the leading causes of traffic congestions at these junctions were poor road infrastructure, commercial activities, and proximity of junctions. The high number of vehicles was also noted as a significant cause of the traffic congestions. In support of our findings, several studies (Bashiru and Waziri 2008; Aworemi et al. 2009; Aderamo and Atomode 2011) have noted that poorly designed junctions contribute significantly to traffic congestions. Ukpata (2012) pointed out that economic activities at the road links or junctions in Nigeria's urban city major cause traffic congestion.

As established from past studies, one of the significant reasons road traffic congestions persists is the spatial spread of traffic junctions that impede traffic flow. The long waiting time at the three junctions Agbogbo/Irese/Futa along Ilesa-Benin-Owo Expressway, a common sight on the road network, also causes a Stop and Go driving experience among motorists. This incapacitating situation continues to defy every solution and strategy of the government's approach, arrangement, and countermeasures introduced over the years in major cities, including Akure (Mabogunje,1968; Onakomaiya, 1979; Odeleye, 2001; Ogunsanya, 2002; Oni, 2004; Adalemo, 2005; cited in Joshua et al. 2016).

Our study also showed that the productivity of road users was impacted by the traffic congestions each day. This result is supported by past works such as Kamruzzaman \& Rumpa (2019), Olawale (2012), and Harriet et al. (2013). Harriet et al. (2013) found that traffic congestions reduced commuters' earnings from 20 trips to 15 trips each day and $\mathrm{GH} \notin 50$ to GH $\notin 40$ per trip in Ghana. Olawale (2012) noted that time loss due to congestion has a negative and significant effect on career progression and satisfaction of workers in Lagos metropolis, Nigeria. Kamruzzaman \& Rumpa (2019) examined the impact of road traffic congestion on workers' performance in Dhaka, Bangladesh. The authors found that effectiveness, efficiency, career progression of workers, satisfaction, innovation, and quality of work.

Regarding possible solutions to the traffic congestion at the junctions, the respondents suggested establishing flyovers and buffer zones at the junctions to reduce the currently continuous traffic congestions. The work of Mudiono (2015) supports our study. The author maintains that a Flyover is the most technically efficient solution to traffic congestions at a Jatingaleh highway in Indonesia. Also, Lal et al. (2016) proposed modifications, footpaths, proper road markings, traffic signs, and signals as solutions to the traffic congestion at intersections in developing countries. 


\section{CONCLUSION}

This study aimed to provide case study evidence of the importance of free flow of traffic, time spent in traffic at junctions, and individual productivity of road users along the Ilesa-Owo-Benin expressway in Akure Ondo State, Nigeria. We achieved this aim by retrieving the opinions of over 200 respondents on the different problems associated with traffic congestion at three junctions on the Ilesha-Owo-Benin expressway in Akure City, Nigeria.

We found that road users mostly experience traffic congestions at the three junctions at an average of 20 minutes every day. Traffic congestions occur mostly during the mornings on weekdays. Also, the road users felt that their productivity was impacted due to the time spent in transit at these junctions. Poor road infrastructure, many vehicles on the road, and proximity of the junctions were noted as the cause of the traffic congestions. Potential solutions include establishing a flyover and buffer zones between the junctions.

We acknowledge the limitations of this study to include potential bias that is associated with perception studies. We suggest that field investigation such as road mapping and observation of traffic situations should be carried out at these junctions to illustrate the situation further. That said, our results provide an essential indication of a persisting issue that requires immediate attention. The results of this study are beneficial, not only to the Akure local government. But also, to the person overseeing the transportation networks in Akure city and beyond.

\section{ACKNOWLEDGEMENT}

The authors would like to extend their appreciations to Universiti Sains Malaysia (USM) and this research was supported by USM Short Term Grant (304/PPBGN/6315256).

\section{REFERENCES}

Adalemo, I. A (2005). 'From Fishing Village to Sprawling Metropolis: The growth and spatial expansion of Lagos, Nigeria.' Keynote Address presented at the National Conference on the Lagos Region titled Planning and Management of Lagos Environment, Geography Dept., University of Lagos, Nigeria

Aderamo, A. J., \& Atomode, T. I. (2012). Traffic congestion at road intersections in Ilorin, Nigeria. Mediterranean Journal of Social Sciences, 3(2), 201213. https://doi.org/10.5901/mjss.2012.v3n2.20 Agatz, N. et al. (2012). Optimisation for dynamic ridesharing: A review. European Journal of Operational Research 223, 2, 295-303.

Agbonika, F.O. (2011). Road Traffic Congestion and the quest for effective Transportation. Proceedings of the National Conference of Nigerian Society of Engineers in Calabar. 
Omotayo Fatai Ogunyemi, Diana Binti Mohamad, Nurwati Badarulzaman, Abdul Ghapar Othman

Traffic Congestions, Time Spent at The Expressway Junctions, And Its Impact on Individual Productivity: A

Perception Study of Ilesa-Owo-Benin Expressway in Akure Ondo State, Nigeria

Bashiru, A. R. and Waziri, O. O. (2008). Analysis of intra Urban Traffic Problems in Nigeria: A study of Lagos Metropolis. Indonesian Journal of Geography 40 (1), 31-51.

European Commission Transport Road Safety (2020), Mobility and Transport: Road Safety https://ec.europa.eu/transport/road_safety Accessed; 06/05/2020

Fadairo, G. (2013). Traffic Congestion in Akure, Ondo State, Nigeria: Using Federal University of Technology Akure Road as a case study. International Journal of Arts and Commerce (Vol. 2). Retrieved from www.ijac.org.uk

Fitzpatrick, Kay, Wooldridge, Mark, D., Blaschke, Joseph, D. (2005) Urban Intersection Design Guide: Volume 1 - Guidelines", Report No: FHWA/TX-05/0-4365-P2 Vol. 1

Harriet T., Poku K. \& Emmanuel A. (2013). An assessment of traffic congestion and its effect on productivity in urban Ghana International Journal of Business and Social Science, 4 (3)

Joshua A. O. Iyiola O. (2016), Integration of Road Carrying Capacity and GIS as a tool for Network Planning: A study of road traffic congestion in selected corridors of metropolitan Lagos, Nigeria.

Kamruzzaman, M. \& Rumpa, Z. F. (2019). The effect of traffic congestion on employee productivity in Dhaka, Bangladesh. The International Journal of Business \& Management, 7(5). doi:10.24940/theijbm/2019/v7/i5/bm1811023

Lal, G., Divya, L., Nithin, K., Mathew, S., \& Kuriakose, B. (2016). Sustainable traffic improvement for urban road intersections of developing countries: A case study of Ettumanoor, India. Procedia Technology, 25, 115-121. doi: 10.1016/j.protcy.2016.08.088

Mabogunje, A. L. (1968). Urbanisation in Nigeria. African Publishing Corp. N.Y.

Moses, S. O. (2011). Information technology applications in transportation system. Proceedings of the National Conference of Nigerian Society of Engineers in Calabar.

Mudiono R. (2015) Research of Flyover as a Solution to Congestion of Intersection Junction A Case Study: Jalan Jatingaleh Semarang. Proceedings of International Conference: Issues, Management And Engineering In The Sustainable Development On Delta Areas. Semarang, Indonesia-February 20th, 2015

Odeleye, J. A. (2001). 'Managing Road Traffic Congestion in a Megacity: Case of Metropolitan Lagos, Nigeria,' in Ming Sun (ed) Proceeding of International Conference of Postgraduate Research in the Built and Human Environment, The University of Salford U.K.

Ogunsanya A.A. (2002). National Transport Policy for Nigeria - Highlights of Issues; Report of the 5th Meeting of the National Council on Transport 29th -31 st August.

Olawole, M.O. (2012). Accessibility to Lagos bus rapid transit (BRT LITE) bus stops: An empirical study. Paper presented at the International Conference on the role of urban mobility in (re)shaping cities -CODATU XV 22 to 25 October Addis Ababa (Ethiopia) Retrieved from http://www.codatu.org/wpcontent/uploads/M.O.-Olawole-ARTICLE-Codatu-X 
Onakomaiya S. O. (1979). 'Through Traffic in Three Cities: A Comprehensive Analysis.' Nigerian Geographical, Vol. 22.

Oni, S. I. (2004). 'Urbanisation and Transportation Development in Metropolitan Lagos,' in Adejugbe M. O.A (ed.) Industrialization, Urbanization, and Development in Nigeria 1950 - 1999, Concept Publications Limited, Lagos, Nigeria.

Singha, M. R., \& Kalita, B. (2016). Uninterrupted Traffic Flow at Junctions with Particular Reference to Guwahati City Uninterrupted Traffic Flow at Junctions with Special Reference to Guwahati City. (February 2014 "Available at http://beate- weber.de/wort3.

Ukpata J. O \& Etika A. A. (2012). Traffic Congestion in Major Cities of Nigeria International Journal of Engineering and Technology 2(8): 1433-1438.

Received: $5^{\text {th }}$ November 2021. Accepted: $5^{\text {th }}$ December 2021 